\title{
Subjective evaluation
}

\section{of health and preventive care}

\section{of the musculoskeletal system}

\section{among current high school students}

\author{
Jana Kvintová, Martin Sigmund, \\ Michal Kudláček, Iva Dostálová
}

\begin{abstract}
The submitted study represents a part of an extensive study focused on health and condition of the auxiliary musculoskeletal system in current high school and university students. Based on our research practice we can state that the functional condition of the musculoskeletal system of Czech high school and university students is unsatisfactory. The data of several research subsets have been presented within this research project. In order to gain a more complex insight into the area of the auxiliary musculoskeletal system, we carried out a questionnaire-style research focused on subjective evaluation of health and its individual components. A total of 1022 high school students took part in this research, and 569 university students were used to compare the results. Besides that, the high school students took part in a survey to assess complementary activities aimed at improving the auxiliary musculoskeletal system. The goal of this survey was to assess the subjective level of health and its components in present-day high school students, and simultaneously evaluate activities connected to the care of the auxiliary musculoskeletal system. The outputs of this survey may serve for future work with students and for overall improvement of the functional auxiliary musculoskeletal system, and thus health in general. We assume that the submitted findings will be used
\end{abstract}


in further work with our students in terms of health, healthy growth and development, and the prevention of negative phenomena in the area of the musculoskeletal system.

Key words: health education, health promotion, students.

\section{Introduction}

The assessment of the condition and functioning of the musculoskeletal system can be considered as an important part of man's health. The World Health Organization (WHO) defines health as "the state of complete physical, mental and social well-being, not merely the absence of disease or infirmity" (WHO, 2016). This progressive definition has become an important divide in viewing the whole problem of health as an area, where besides the biological aspect, the social aspect of health and illness is important, too. The fact that the definition places an emphasis on wholeness or whole as the main feature of health at all is valuable. At the same time, it accentuates health as a positive, generally desired value (Křivohlavý, 2009; Payne et al., 2005).

The way an individual maintains his health, besides endogenous dispositions, depends mainly on a complex of behavioral aspects. Currently, these aspects relating mainly to the individual behavior of an individual are classified within the term lifestyle. Thus lifestyle represents one of the most important protective health factors (Pluijm et al, 2007). Lifestyle and personal behavior influence the health of an individual in 50-60\% (Dolanský, 2008; Machová \& Kubátová, 2009). Its influence takes effect in a whole range of life areas - family, school, workplace, leisure time activities, etc. In case we want to influence the health and lifestyle of an individual in a positive context and within primary prevention, it is necessary to start with the youngest age categories. The position of the WHO is that the behavior and lifestyle in adulthood are the results of a person's development in childhood and adolescence. From the viewpoint of public health, the monitoring of the occurrence of behavioral components affecting the health of children and adolescents is important (Kalman, Hamřík, \& Pavelka, 2009).

If we significantly connect the lifestyle of an individual with his musculoskeletal activity, we can speak of an active lifestyle. That is considered as a certain system of important activities and relations and interconnected practices focused on achieving a full-fledged and harmonious state between the physical and mental sides of men (Valjent, 2008).

Musculoskeletal activity has accompanied man since the beginning of his evolution. In the past 50000 years of the so-called Homo sapiens sapiens, only small changes have modified life functions of men. Compared to hunters and gatherers, an urbanized man of the present day is exposed to totally different life conditions. Mainly a lack of movement and excessive energy intake characteristic for sedentary lifestyle lead to 
regulatory systems disorders that were set up for different life conditions (Stejskal, 2004). Musculoskeletal inactivity in combination with bad eating habits then lead to the occurrence of multiple noninfectious diseases that are currently the cause of $60 \%$ of all deaths in the world (WHO). Sedentary lifestyle is represented by a lack of physical activity (PA) both at work and during one's leisure time. Fatigue caused by psychological stress and a lack of movement decreases man's activity so much that he consumes more than he gives out. These facts are then negatively demonstrated in multiple physical systems, lead to the onset of the above mentioned diseases and decrease an individual's quality of life in general.

Negative influences will thus demonstrate also on the condition of the auxiliary musculoskeletal system. The condition of the present-day population in the area of the musculoskeletal system is very unsatisfactory. Various disorders in the area of the muscle system that are one of the significant causes of painful conditions of the musculoskeletal system are diagnosed increasingly often (Dostálová, Sigmund, \& Kvintová, 2013; Koláŕ et al., 2009; Kopecký, 2010; Véle, 2012). For optimum functioning of the skeletal muscles there needs to be an optimum functional ratio between the postural and phasic muscles. The trend of unsatisfactory condition of the auxiliary musculoskeletal system is now observed even in the youngest age categories, and it is closely related to the school regimen of children that does not allow spontaneous musculoskeletal activity, and thus helps to give rise to such disorders. The static-dynamic function of the musculoskeletal system is disrupted, which leads to various musculoskeletal substitutions, clinical syndromes, and a decrease in the tolerance threshold of physical stress (Koláŕ, 2006). Based on our own survey we can state that the highest occurrence of muscular imbalance in high school students was found in knee-joint extensors (71.2\%) and knee-joint flexors (63.7\%) (Dostálová \& Sigmund, 2017). Other frequent areas of muscle shortening are in the lumbar area of spine erectors and the thigh fascia stretcher. It turns out that all significantly higher values of muscle shortening were found in boys compared to girls. Different occurrence of muscular imbalance is not monitored only in hypokinetic individuals but also in the sporting population, thus becoming one of the biological risk factors that limit sport performance and contribute to the origination of various injuries and premature development of degenerative disorders of the auxiliary musculoskeletal system (Dostálová, 2013). The need for increased attention paid to the auxiliary musculoskeletal system is mainly accented in children and youth since mainly here it is possible to effectively help, namely in the sense of primary prevention. For this reason, it is necessary to discover such problems in time and rectify them using a suitable corrective activity in respect to the individual needs of every individual.

The submitted study represents a part of an extensive study focused on the health and condition of the auxiliary musculoskeletal system in present-day high school and college students. In order to gain a more complex insight into the area of the auxiliary musculoskeletal system, we carried out a questionnaire-style research focused on subjective evaluation of health and its individual components. 
Besides that, the high school students took part in a survey to assess complementary activities aimed at improving the auxiliary musculoskeletal system.

Based on our research practice we can state that the functional condition of the musculoskeletal system of Czech high school and university students is unsatisfactory. The data of several research subsets have been presented within this research project.

We asked the following research questions: 1). What is the level of subjectively perceived health in present-day high school students? 2). What preventive measures in respect to preventive care of the auxiliary musculoskeletal system do present-day high school students apply?

The goal of this research is to assess the subjective level of health and its components in present-day high school students, and simultaneously evaluate activities relating to the care of the auxiliary musculoskeletal system.

\section{Methods}

\section{Research sample}

The study involved a total of 1022 high school students ( $49 \%$ boys; $51 \%$ girls) from selected high school in Olomouc and North Moravian region and 569 university students (37\% male; $63 \%$ female) from Palacký University in Olomouc. The survey and data collection were carried out in year 2015. In terms of age, the study was conducted on high school students aged from 16 to 19. The overall age variability of the research sample of university students was between 19 and 26 years. Data of university students are presented for comparison with the main target group of high school students.

In terms of ethical aspects, all participants in the survey were fully informed of its purpose and of a possibility to terminate their participation at any time without giving a reason. All participants were informed of further data processing and ensuring anonymity. Each participant was involved on a voluntary basis and consented to data processing and publication.

\section{Data collection methods}

To assess the current level of life satisfaction, the research study used a standardized psychodiagnostic tool - Life Satisfaction Questionnaire (LSQ) (Rodná \& Rodný, 2001). The Czech version of the LSQ is based on the original German questionnaire Fragebogen zur Lebenszufriedenheit (FLZ) (Fahrenberg, Myrtek, Schumacher, \& Brähler, 2000). The LSQ is designed for standardized description of inter-individual and intra-individual life satisfaction variability. Each of the specified items contains seven statements. For each statement in each item the respondent tries to express the current level of satisfaction by selecting on a seven-grade scale; $1=$ very dissatisfied, $7=$ very satisfied. The Health item was elaborated and analyzed in more detail. Furthermore, the question- 
naire was applied focusing on issues related to alternative musculoskeletal system. The items related to PA warming up, compensatory-corrective activities, the incidence of chronic diseases and the overall issue of alternative care for musculoskeletal system were evaluated.

\section{Statistical analysis}

Statistical result processing was conducted using the Statgraphics programme v. 12.0 (Statistica, Tulsa, USA). For each variable, basic statistical quantities were calculated and distribution normality verified. Normality was assessed using the Shapiro-Wilk normality test. For the assessment of differences in mean values independent sets of two-sided Student t-test were applied. Evaluation of the questionnaire responses was performed using contingency tables, chi-square test. The level of statistical significance was tested at $p \leq 0.05 ; p \leq 0.01$. To assess Effect of Size, the Cohen's coefficient defined as a difference between two means divided by a standard deviation for the data, where the value of $d 0.2=$ small effect, $d 0.5=$ medium effect and $d 0.8=$ large effect (Cortina \& Nouri, 2000; Thomas, Nelson, \& Silverman 2011) was applied.

\section{Results and Discussion}

The results section presents the main findings concerning subjective assessment of health and preventive care of the musculoskeletal system in the research sample of current high school students. To compare the results in the area of health, the authors used reference data and data based on their own research aimed at university students.

In the group of high school students, the authors observed an overall lower level in the assessment of own health compared with reference values based on the Life Satisfaction Questionnaire. A comparison of the overall values of the level of health and its subcomponents with the sample of university students suggests statistically and materially insignificant differences between high school students and university students (Table 1). A detailed analysis by gender revealed a trend of higher satisfaction with own health in male respondents, both among high school students and university students. These findings are consistent with other studies aimed at the issue of health (Kvintová, Sigmund, \& Hřebíčková, 2014; Kvintová \& Sigmund, 2012). 
Table 1

Level of subjectively perceived health and its components on current high school students compared to university students

\begin{tabular}{|c|c|c|c|c|c|c|c|}
\hline \multirow{2}{*}{ Health } & \multicolumn{2}{|c|}{ High school students ( $n=1022)$} & \multicolumn{2}{|c|}{ University students ( $n=569$ ) } & \multirow[b]{2}{*}{$\Delta$} & \multirow[b]{2}{*}{$p$} & \multirow[b]{2}{*}{$d$} \\
\hline & $M \pm S D$ & Range & $M \pm S D$ & Range & & & \\
\hline Somatic health condition & $5.1 \pm 1.28$ & $1-7$ & $5.0 \pm 1.39$ & $1-7$ & 0.1 & ns & 0.08 \\
\hline Mental condition & $5.2 \pm 1.40$ & $1-7$ & $5.2 \pm 1.42$ & $1-7$ & 0 & ns & 0.00 \\
\hline Physical condition & $4.7 \pm 1.38$ & $1-7$ & $4.5 \pm 1.53$ & $1-7$ & 0.2 & ns & 0.14 \\
\hline Mental performance & $5.1 \pm 1.34$ & $1-7$ & $5.3 \pm 1.27$ & $1-7$ & 0.2 & ns & 0.15 \\
\hline Immunity & $5.2 \pm 1.67$ & $1-7$ & $5.1 \pm 1.52$ & $1-7$ & 0.1 & ns & 0.06 \\
\hline Pain frequency & $4.6 \pm 1.53$ & $1-7$ & $4.5 \pm 1.69$ & $1-7$ & 0.1 & ns & 0.06 \\
\hline Disease frequency & $5.0 \pm 1.59$ & $1-7$ & $4.9 \pm 1.74$ & $1-7$ & 0.1 & ns & 0.06 \\
\hline Health Total & $32.6 \pm 6.36$ & $11-45$ & $33.0 \pm 6.73$ & $11-49$ & 0.4 & ns & 0.06 \\
\hline
\end{tabular}

Legend: $\mathrm{n}$ - frequency; $\mathrm{M}$ - arithmetic mean; $\mathrm{SD}$ - standard deviation; $\Delta$ - difference; $p$ - statistical significance; $\mathrm{ns}$ - non significant; $d$-Cohen's $d$ Effect of Size

\subsection{Results of a questionnaire survey aimed at physical activity and care of the musculoskeletal system in current high school students aged 16 to 19 years}

The question on PA asked how often current high school students pursued PA. The answer 'regularly' indicated physical activity at least three times a week of at least 60 minutes (in total 180 minutes). It was observed that $56 \%$ of high school students indicated regular PA. A significantly higher proportion of regular PA was observed in boys compared with girls (Table 2). Irregular PA was reported by $40 \%$ of high school students with significantly higher values in girls. No PA was reported by $4 \%$ of high school students with a higher proportion of girls. In relation to PA, it was observed that $29 \%$ of high school students considered themselves active athletes. A significantly higher proportion was observed in boys compared with girls (Table 2). In terms of caring for the musculoskeletal system, the survey focused on how students performed a warm-up before physical activity. The answer'regularly' indicated a warm-up prior to any PA. A total of $42 \%$ of students reported a regular warm-up. This was indicated by an insignificantly higher proportion of boys compared with girls. $47 \%$ of respondents reported an irregular warm-up prior to PA, and $11 \%$ of reported no warm-up. The difference between the answers of boys and girls was statistically insignificant (Table 2). In terms of caring for the musculoskeletal system, the survey also focused on how stu- 
dents performed compensation and corrective activities after PA. The answer 'regularly' indicated compensation and corrective activities aimed particularly at the muscular system after completion of any PA. A total of $19 \%$ of students reported regular compensation and corrective activities. $52 \%$ of respondents reported irregular and $19 \%$ no compensation activities. The difference between the answers of boys and girls was statistically insignificant (Table 2). The incidence of chronic diseases in the sample of high school students represents $20 \%$, with identical values in boys and girls (Table 2). In terms of specific diseases, the most frequently reported diseases were allergy and type 1 diabetes mellitus. The respondents indicated negligible incidence of chronic diseases associated with the musculoskeletal system.

Table 2

Current high school students - physical activity and chronic diseases

\begin{tabular}{|c|c|c|c|c|c|c|c|}
\hline & \multicolumn{2}{|c|}{$\begin{array}{c}\text { Total } \\
(n=1022)\end{array}$} & \multicolumn{2}{|c|}{$\begin{array}{c}\text { Boys } \\
(n=502)\end{array}$} & \multicolumn{2}{|c|}{$\begin{array}{c}\text { Girls } \\
(n=520)\end{array}$} & \multirow{2}{*}{$\begin{array}{c}\text { Chi-square } \\
X^{2} \\
(C h \times D)\end{array}$} \\
\hline & $n$ & $\%$ & $n$ & $\%$ & $n$ & $\%$ & \\
\hline \multicolumn{8}{|c|}{ Physical activity } \\
\hline Regularly & 569 & 56 & 329 & 66 & 240 & 46 & $8.117^{* *}$ \\
\hline Irregularly & 405 & 40 & 157 & 31 & 248 & 48 & $6.047^{*}$ \\
\hline None & 48 & 4 & 16 & 3 & 32 & 6 & 1.047 \\
\hline \multicolumn{8}{|c|}{ Physical activity - registered athletes } \\
\hline Yes & 296 & 29 & 190 & 38 & 106 & 20 & \multirow{2}{*}{$7.868^{* *}$} \\
\hline No & 726 & 71 & 312 & 62 & 414 & 80 & \\
\hline \multicolumn{8}{|c|}{ Physical activity - warming } \\
\hline Regularly & 434 & 42 & 241 & 48 & 193 & 37 & 2.476 \\
\hline Irregularly & 475 & 47 & 224 & 45 & 251 & 48 & 0.181 \\
\hline None & 113 & 11 & 37 & 7 & 76 & 15 & 3.269 \\
\hline \multicolumn{8}{|c|}{ Physical activity - stretching, compensatory-corrective activity } \\
\hline Regularly & 198 & 19 & 97 & 19 & 101 & 19 & 0 \\
\hline Irregularly & 532 & 52 & 249 & 50 & 283 & 55 & 0.501 \\
\hline None & 292 & 29 & 156 & 31 & 136 & 26 & 0.613 \\
\hline \multicolumn{8}{|c|}{ Chronic diseases } \\
\hline Yes & 203 & 20 & 98 & 20 & 105 & 20 & \multirow{2}{*}{0} \\
\hline No & 819 & 80 & 404 & 80 & 415 & 80 & \\
\hline
\end{tabular}

The assessment of ergonomic measures in relation to the musculoskeletal system focuses on whether the respondent uses for example a suitable chair, has a well-organized workplace (space, desk), uses a suitable bed (frames, mattress), anatomically shaped 
backpack, luggage on wheels, handles objects in a proper way, etc. A total of $17 \%$ of high school students reported that they applied ergonomic measures in terms of caring for their musculoskeletal system. This was indicated by a significantly higher proportion of boys compared with girls (Table 3). The question on activities associated with good posture focuses on whether the respondent performs posture correction in various positions regularly throughout the day. A total of $41 \%$ of high school students reported regular posture correction with a significant predominance of boys. The question on the application of water regeneration procedures asks whether these activities are a regular part of caring for the musculoskeletal system. A total of $13 \%$ of high school students indicated the application of water regeneration procedures as a regular part of caring for their musculoskeletal system. This was indicated by a significantly higher proportion of boys compared with girls. The use of appropriate footwear was the subject of a separate question because caring for the leg and the foot significantly determines the overall condition of the musculoskeletal system. A total of $17 \%$ of high school students reported the use of appropriate footwear. This was indicated by a significantly higher proportion of boys (31\%) compared with girls (4\%) (Table 3). The question on active health exercise asks whether the respondent deliberately performs PA associated with compensation and corrective activities aimed at the musculoskeletal system at least once a week. A total of $17 \%$ of high school students reported such activity. This was indicated by a significantly higher proportion of boys compared with girls. A total of $10 \%$ of high school students reported regular use of medicine. Regular use of food supplements was reported by a total of $23 \%$ of high school students. The use of food supplements was indicated by a significantly higher proportion of boys ( $37 \%) \mathrm{com}$ pared with girls (9\%) (Table 3 ).

Table 3

Current hight school students and alternative care for musculoskeletal system

\begin{tabular}{|c|c|c|c|c|c|c|c|}
\hline \multirow{2}{*}{$\begin{array}{l}\text { Alternative care } \\
\text { for musculoskeletal system }\end{array}$} & \multicolumn{2}{|c|}{$\begin{array}{c}\text { Total } \\
(n=1022)\end{array}$} & \multicolumn{2}{|c|}{$\begin{array}{c}\text { Boys } \\
(n=502)\end{array}$} & \multicolumn{2}{|c|}{$\begin{array}{c}\text { Girls } \\
(n=520)\end{array}$} & \multirow{2}{*}{$\begin{array}{c}\text { Chi-square } \\
x^{2} \\
(C h \times D)\end{array}$} \\
\hline & $n$ & $\%$ & $n$ & $\%$ & $n$ & $\%$ & \\
\hline \multicolumn{8}{|l|}{ Ergonomic measures } \\
\hline Yes & 177 & 17 & 143 & 29 & 34 & 7 & \multirow{2}{*}{$16.396^{* *}$} \\
\hline No & 845 & 83 & 359 & 71 & 486 & 93 & \\
\hline \multicolumn{8}{|c|}{ Activities related to the right to possession } \\
\hline Yes & 414 & 41 & 373 & 74 & 41 & 8 & \multirow{2}{*}{$90.037^{* *}$} \\
\hline No & 608 & 59 & 129 & 26 & 479 & 92 & \\
\hline
\end{tabular}




\begin{tabular}{|c|c|c|c|c|c|c|c|}
\hline \multicolumn{8}{|c|}{ Water regeneration procedures } \\
\hline Yes & 131 & 13 & 99 & 20 & 32 & 6 & \multirow{2}{*}{$8.665^{* *}$} \\
\hline No & 891 & 87 & 403 & 80 & 488 & 94 & \\
\hline \multicolumn{8}{|c|}{ The use of appropriate footwear } \\
\hline Yes & 178 & 17 & 156 & 31 & 22 & 4 & \multirow{2}{*}{$25.247^{* *}$} \\
\hline No & 844 & 83 & 346 & 69 & 498 & 96 & \\
\hline \multicolumn{8}{|c|}{ Active health exercise } \\
\hline Yes & 203 & 20 & 98 & 20 & 105 & 20 & \multirow{2}{*}{$14.174^{* *}$} \\
\hline No & 819 & 80 & 404 & 80 & 415 & 80 & \\
\hline \multicolumn{8}{|c|}{ Regular use of drugs } \\
\hline Yes & 106 & 10 & 63 & 13 & 43 & 8 & \multirow{2}{*}{1.330} \\
\hline No & 916 & 90 & 439 & 87 & 477 & 92 & \\
\hline \multicolumn{8}{|c|}{ Regular use of supplements } \\
\hline Yes & 234 & 23 & 186 & 37 & 48 & 9 & \multirow{2}{*}{$22.134^{* *}$} \\
\hline No & 788 & 77 & 316 & 63 & 472 & 91 & \\
\hline
\end{tabular}

Deliberate PA and other preventive activities aimed at supporting the musculoskeletal system represent an important part of caring for the musculoskeletal system of an adolescent. Research studies performed by the authors suggest that the functional state of the musculoskeletal system in Czech students is unsatisfactory. Therefore, it is imperative to work with the students on a practical level in terms of preventing or compensation of negative functional consequences. It is also important to implement theoretical knowledge in classes and educational curricula in order to improve the education of health and healthy behavioral aspects relating to the musculoskeletal system - both in terms of primary and secondary prevention with the application of appropriate compensation and corrective activities. Horkel and Horklová (2004) confirmed that training exercise incorporated in school-based physical education significantly improved muscle balance. At the same time, however, stated that physical education lessons contained little or no training exercise focused on muscle balance. The selection of activities should primarily focus on differentiated elimination of insufficiencies in the physical development and PA of students with regard to their individual needs. Most functional disorders and painful areas in children and youth are located in the lumbar and pelvic regions. The incidence of pain correlates with age, length and type of PA (Thurzová, 2003).

It is therefore necessary for children's PA to include from an early age a variety of corrective activities in order to eliminate muscle imbalances and to maintain an optimum condition of the musculoskeletal system or correct any existing disorders and substitutions (Dostálová, Sigmund, \& Kvintová, 2013). Disorders of muscle functions and locomotive stereotypes were observed both in children with low PA and children 
subject to unilateral load during sport. If special compensation exercise is not used, PA and high fitness are not sufficient to protect children and adolescents from muscle imbalances. Functional muscle imbalance should be a sufficient incentive for the development of optimal physical activity programs in the school environment.

\section{Conclusions}

The main results of the present survey aimed at subjective assessment of health and care of the musculoskeletal system in high school students are as follows:

- Subjective assessment of health in current high school students and university students is lower than reference values,

- subjective assessment of health and its subcomponents in current high school students and university students is almost identical and shows insignificant differences,

- $56 \%$ of high school students report regular PA, with a significant predominance of boys,

- $29 \%$ of high school students report their active engagement in sport, with a significant predominance of boys,

- $42 \%$ of high school students report regular warm-up prior to PA,

- $19 \%$ of high school students report regular compensation and corrective activities after PA

- $20 \%$ of high school students report the incidence of chronic disease,

- $17 \%$ of high school students report the application of ergonomic measures in terms of caring for the musculoskeletal system, with a significant predominance of boys,

- $41 \%$ of high school students report regular posture correction, with a significant predominance of boys.

- $13 \%$ of high school students report regular application of water regeneration procedures as a part of caring for the musculoskeletal system, with a significant predominance of boys,

- $17 \%$ of high school students report the use of appropriate footwear, with a significant predominance of boys,

- $17 \%$ of high school students report active health exercise at least once a week aimed at compensation and corrective activities with a focus on the musculoskeletal system,

- $10 \%$ of high school students report regular use of medicine,

- $23 \%$ of high school students report regular use of food supplements, with a significant predominance of boys. 
This study represents a part of an extensive research aimed at the condition of the musculoskeletal system in Czech students. This particular part focuses on high school students, whose functional state of the muscular system is unsatisfactory. Compensation and corrective activities do not include only specific types of PA but also other activities that can positively affect the quality of the locomotor system. Some of them were indicated in the mentioned study. Generally, the results are unsatisfactory. The outcomes of the survey can be used for further work with students and for overall improvement of the functional state of the musculoskeletal system and health in general. This should prevent further deterioration of the function of the musculoskeletal system in children and youth that could lead to more serious disorders of the musculoskeletal system. We assume that the findings will be used in further work with students in terms of promoting health, healthy growth and development, and prevention of negative phenomena concerning the musculoskeletal system.

\section{Acknowledgement}

The study was supported by the following grant project: Internal grant of PDF UP: Psychosocial determinants of health among subjects in educational environment and IGA_PdF_2016_020 Selected psychosocial factors affecting the health of current University students of teaching.

\section{References}

Cortina, J. M., \& Nouri, H. (2000). Effect size for ANOVA design. Thousand Oaks, CA: Sage publications. Dolanský, H. (2008). Veřejné zdravotnictví. Opava: Slezská univerzita v Opavě.

Dostálová, I., Sigmund, M. (2017). Pohybový systém. Olomouc: Poznání.

Dostálová, I., Sigmund, M., \& Kvintová, J. (2013). Theoretical and practical aspects of health physical education in the Czech Republic. e-Pedagogium, 2, 110-124.

Fahrenberg, J., Myrtek, M., Schumacher, J. \& Brähler, E. (2000). Fragebogen zur Lebenszufriedenheit (FLZ). Handanweisung. Göttingen: Hogrefe.

Horkel, V., \& Horklová, H. (2004). Úroveň svalové nerovnováhy u žáků 2. stupně základní školy. In M. Nosek (Ed.), Sborník referátů z vědeckého semináře s mezinárodní účastí Pohyb a výchova (pp. 33-36). Ústí nad Labem: Univerzita Jana Evangelisty Purkyně.

Kalman, M., Hamř́k, Z. \& Pavelka, J. (2009). Podpora pohybové aktivity: Pro odbornou veřejnost. Olomouc: Ore - Institut.

Kolář, P. (2006). Vertebrogenní obtíže a stabilizační funkce svalů - diagnostika. Rehabilitace a fyzikální lékařství, 4, 155-170.

Kolář, P. et al. (2009). Rehabilitace v klinické praxi. Praha: Galén.

Kopecký, M. (2010). Zdravotní tělesná výchova. Olomouc: Univerzita Palackého, Fakulta tělesné kultury.

Křivohlavý, J. (2009). Psychologie zdraví. Praha: Portál. 
Kvintová, J., \& Sigmund, M. (2012). Psychosocial Aspects of Stress in Current University Students. e-Pedagogium, 4, 59-69.

Kvintová, J., Sigmund, M., \& Hřebíčková, H. (2014). Live satisfaction and subjective health assessment in future teachers compared with current university students of physical culture and natural science. e-Pedagogium, 2, 15-30.

Machová, J., \& Kubátová, D. et al. (2009). Výchova ke zdraví. Praha: Grada.

Payne, J. a kol. (2005). Kvalita života a zdraví. Praha: Triton.

Pluijm, S. M. F., Visser, M., Puts, M. T. E., Dik, M. G., Schalk, B. W. M., Van Schoor, N. M., Schaap, L. A., Deeg, D. J. H., \& Bosscher, R. J. (2007). Unhealthy lifestyles during the life course: association with physical decline in late life. Aging Clinical and Experimental Research, 19(1), 75-83.

Rodná, K., \& Rodný, T. (2001). Dotazník životní spokojenosti. Praha: Testcentrum.

Sigmund, M., Kvintová J., Hřebíčková, Šafář, M., \& Sigmundová, D. (2014). Live satisfaction, health, self-evaluation and sexuality in current university students of sport sciences, education and natural sciences. Acta Gymnica, 44(4), 231-241.

Sigmund, M., Kvintová, J., Dostálová, I., \& Hamřík, Z. (2013). Selected personality traits and achievement motivation in university students of physical culture, education and natural sciences. Acta Universitatis Palackianae Olomucensis. Gymnica, 43(3), 37-47.

Stejskal, P. (2004). Proč a jak se zdravě hýbat. Břeclav: Presstempus.

Thomas, J. R., Nelson, J. K., \& Silverman, S. J. (2011). Research methods in physical activity (6th ed.). Champaign, IL: Human Kinetics.

Thurzová, E. (2003). Bolest’ pohybového aparátu u mladých športovcov. Telesná výchova a šport, 13(1), 31-35.

Valjent, Z. (2008). Pokus o vymezení pojmu Aktivní životní styl. Česká kinantropologie, 12(2), 42-50.

Véle, F. (2012). Vyšetření hybných funkcí. Praha: Triton.

WHO (2003). WHO definition of Health. Retrieved on 4. 12. 2013 from the World Wide Web: http:// www.who.int/about/definition/en/print.html

WHO (2016).World Health Organization. Retrieved on 21. 10. 2016 from the World Wide Web: http://www.who.int/about/mission/en/

\section{Contact:}

PhDr. Jana Kvintová, Ph.D.

Faculty of Education, Palacký University Olomouc

Žižkovo nám. 5, 77140 Olomouc

Czech Republic

E-mail: jana.kvintova@upol.cz 